\title{
Gibberellin Control of Reproductive Transitions in Brassica oleracea Curd Development
}

\author{
Denise V. Duclos and Thomas Björkman ${ }^{1}$ \\ Department of Horticulture, New York State Agricultural Experiment Station, Cornell University, \\ 630 W. North Street, Geneva, NY 14456
}

\begin{abstract}
AdDitional INDEX words. bracts, Brassica oleracea, broccoli, cauliflower, floral development, flower initiation, growth regulator, vegetative meristem, inflorescence meristem, floral meristem, meristem-identity genes, plastochron

Abstract. Cauliflower (Brassica oleracea var. botrytis) and broccoli (B. oleracea var. italica) differ in the developmental stage of the reproductive meristem at harvest. A cauliflower head is formed by arrest at the inflorescence meristem stage and broccoli at the flower bud stage, and the horticultural value of the crop depends on synchronous development across the head. In other plant species, gibberellin (GA) can promote floral development and is therefore a candidate for providing the early developmental cues that shape the curd morphology. This research investigated the effect of GAs on the two horticulturally important transitions of the reproductive meristem: initiation of the inflorescence meristem and initiation of floral primordia on the proliferated inflorescence meristems. GA is known to affect the former in many species, but effects on the latter have not been determined. It is also not known whether one or both active forms produced by the two GA biosynthetic pathways is involved in the reproductive transitions in this crop. GAs from the early-13 hydroxylation pathway (GA $A_{3}$ ) and the non-13 hydroxylation pathway $\left(\mathrm{GA}_{4+7}\right)$ were applied to the shoot apical meristems of cauliflower and broccoli at three developmental stages: adult-vegetative, curd initiation, and curd enlargement. GAs applied during the adult vegetative stage caused the curd to form faster and after fewer additional nodes in both cauliflower and broccoli. GAs applied to the inflorescence meristem did not cause floral primordia to form nor did the expression of transitionassociated genes change. Integrator genes $B o L F Y$ and $S O C 1$ had constant expression over 24 hours, and meristemidentity genes $B o A P 1-a$ and $B o A P 1-c$ remained undetectable. However, GAs applied early during the reproductive phase increased bract development in cauliflower curds. This study shows that GAs from both pathways can trigger the vegetative-to-reproductive transition in both cauliflower and broccoli, resulting in earlier curd formation. However, GAs did not advance the inflorescence-meristem-to-floral-primordium transition; on the contrary, they increased bract incidence in cauliflower, a sign of reversion toward the vegetative stage, suggesting that another pathway is responsible for this second transition in cauliflower and broccoli.
\end{abstract}

There are three main steps in the process that leads to flowering: a switch from vegetative to inflorescence meristem, a switch from inflorescence meristem to floral primordium, and floral bud development. Distinguishing these processes in most plants has been difficult, because they may occur simultaneously in different regions of a small meristem. The large meristem size, synchronized development, and eventual developmental arrest in cauliflower and broccoli inflorescences allow greater temporal resolution of these transitions. The curd phenotype in cauliflower is comprised of inflorescence meristems that share characteristics of both vegetative and reproductive apices (Sadik, 1962). In broccoli, the head is composed of flower buds, because developmental arrest occurs before anthesis (Fujime and Okuda, 1996). This arrest is accompanied by an extended proliferation of meristems followed by the coordinated induction of floral primordia.

Distinguishing the regulation of individual developmental steps is of practical importance for cauliflower and broccoli breeding and production. In breeding, it is difficult to restore the cauliflower phenotype to commercial standards in the progeny of a cross outside cauliflower, resulting in a very narrow genetic base among cauliflower cultivars and limited introgression of

Received for publication 16 Sept. 2014. Accepted for publication 19 Nov. 2014. We thank Dr. Peter Davies for providing guidance and expertise in the assay used for gibberellin extraction and Dr. Timothy Setter and Dr. Jill Eccleston for their helpful comments on the manuscript. We deeply appreciate the help and constant support provided by Joseph Shail.

${ }^{1}$ Corresponding author. E-mail: tnb1@cornell.edu. disease resistance genes. A better understanding of the genetic or hormonal cues involved in curd development could result in breeding procedures to select early-generation progeny that are parents of high-quality hybrid cauliflower. In field production of broccoli, asynchronous development of the curd can occur in warm temperatures, rendering the broccoli commercially unacceptable (Farnham and Björkman, 2011). A better understanding of flower initiation and bud enlargement can lead to new preventive measures.

\section{Vegetative to Inflorescence Transition}

In arabidopsis (Arabidopsis thaliana), reproductive induction (vegetative to inflorescence meristem) is controlled by a complex network of five flowering pathways that involve response to daylength, vernalization, carbohydrates, gibberellins, and an age-related autonomous pathway. However, the five pathways ultimately converge on the floral integrator genes leafy ( $L F Y)$, suppressor of overexpression of constans 1 (SOC1), and flowering locus $T$ (FT), upregulating their expression (Blazquez and Weigel, 2000; Simpson and Dean, 2002).

\section{Gibberellin}

Plants produce at least 134 GA compounds, of which six are active and the rest are inactive precursors, modifications, or degradation products. Bioactive GAs are synthesized through two different biosynthetic pathways: the non-13-hydroxylation 
pathway produces $\mathrm{GA}_{4}$ and $\mathrm{GA}_{7}$ and the early-13-hydroxylation pathway (Sponsela and Hedden, 2004) produces $\mathrm{GA}_{1}, \mathrm{GA}_{5}$, and $\mathrm{GA}_{3}$.

The GAs in arabidopsis and other species act through direct and independent upregulation of $L F Y$ and $S O C 1$ transcription for reproductive induction (Blazquez et al., 1998; Bonhomme et al., 2000; Gocal et al., 2001; Moon et al., 2003). In contrast, previous studies reach contradictory conclusions about the effect of GAs in reproductive induction in brassicas. The response was described early (Wittwer and Bukovac, 1957) and was shown to be additive to vernalization in cauliflower (Booij, 1989, 1990). However, the response is not seen consistently. In several studies, GAs did not affect reproductive induction in broccoli (Fontes and Ozbun, 1970) or cauliflower (Aditya and Fordham, 1995; Fernandez et al., 1997). At noninducing temperatures, the cold treatment is sometimes replaced by GA (Fernandez et al., 1997) and sometimes not (Guo et al., 2004). These inconsistencies may result from genetic variation within Brassica for GA responsiveness, variation in the sensitivity to GA among the tissues to which GA was applied, variation in sensitivity during the developmental stage at application, or variable sensitivity to the bioactive GA.

The GA pathway can promote, inhibit, or have no effect on reproductive induction, depending on the plant species. In some species, GAs are in a pathway parallel to vernalization and photoperiod [arabidopsis (Blazquez and Weigel, 2000), Lolium temulentum (King et al., 2001), Crepis tectorum, Samolus parviflorus, Hyoscyamus niger, Brassica napus, Petrosilenum crispum, Daucus carota, and others (Lang, 1957)]. In a second group of species, the GA pathway acts synergistically, accelerating flower induction when all environmental requirements are met but having no effect alone [Pinus sylvestris grafts (Luukkanen and Johansson, 1980), Pinus radiata (Ross et al., 1984), Spathiphyllum petite (King et al., 2000), B. napus var. annua (Dahanayake and Galwey, 1999), and Zantedeschia sp. (Naor et al., 2004)]. Finally, in other species GAs have no effect [long-day plant Sinapis alba (Corbesier et al., 2004)] or inhibit reproductive induction [Fuchsia hybrida (King et al., 2000), Vitis sp. (Boss et al., 2003), Pharbitis nil (King et al., 2000)].

\section{Inflorescence Meristem to Floral Primordium Transition}

The second developmental step is the transition from inflorescence meristem to floral primordium. The curd continues to enlarge as long as reproductive meristems are produced, but it ceases once they are converted to floral meristems. This proliferation is longer in broccoli than in most $B$. oleracea and longer still in cauliflower in which curds are composed entirely of reproductive meristem. The difference between the two crops is the timing of this trigger.

In arabidopsis, the floral primordium differentiates in response to upregulation of meristem-identity genes [ $L F Y$, apetala 1 (AP1), apetala 2 (AP2), fruitfull (FUL), cauliflower $(C A L)$ (Bowman et al., 1993; Ferrandiz et al., 2000; Shannon and Meeks-Wagner, 1993)]. Subsequently, floral buds differentiate in response to upregulation of floral-organ-identity genes $[A P 1, A P 2$, apetala 3 (AP3), pistillata (PI), agamous $(A G)$ (Coen and Meyerowitz 1991; Favaro et al., 2003; Pelaz et al., 2000)].

Okamuro et al. (1996) proposed that GA induces floralmeristem identity in one of three ways: by activating meristem-identity genes, by increasing activity of genes downstream of meristem-identity genes, or by an independent pathway. The first pathway, in which GAs activate meristemidentity genes, occurs in some arabidopsis ecotypes (Posé et al., 2012), Lolium temulentum (King et al., 2001), and Vitis sp. (Yahyaoui et al., 1998). The second pathway, in which GAs maintain the floral identity by activating organ-identity genes downstream of meristem-identity genes, occurs in arabidopsis ecotypes ( $\mathrm{Yu}$ et al., 2004). No examples of an independent pathway have been identified. However, GAs may also inhibit floral bud development [Dimocarpus longan (Huang, 1996) and Mangifera sp. (Oosthuyse, 1995)]. In cauliflower, GAs have not been found to affect floral differentiation once primordia are formed (Booij, 1990).

Near anthesis, $B$. oleracea stems elongate rapidly. In many Brassica species this elongation (bolting) is regulated by GA independently from its role in reproductive induction (Mandel et al., 1992). Here, we test whether GA can trigger that process.

Because the role of GA in reproductive development varies greatly within the plant kingdom, the first objective of this study is to determine if GAs affect the vegetative-to-reproductive transition in cauliflower and broccoli by applying exogenous GAs from both the early-13-hydroxylation pathways and the non-13-hydroxylation pathway during very specific stages of their vegetative development. The second objective of this research is to determine whether GAs affect the onset of the reproductive meristem in cauliflower and floral primordia in broccoli. Measuring whether inflorescence morphology and meristem-identity gene expression change as predicted by any of the models will determine in which of the three ways proposed by Okamuro et al. (1996) GAs control flower differentiation in $B$. oleracea.

\section{Materials and Methods}

Plant material and growth conditions. All experiments were conducted with cauliflower cultivar Somerset (Seedway, Hall, NY) and broccoli cultivar Barbados (Bejo Seeds, Oceano, CA), both early-maturing cultivars that grow well in the greenhouse and have little or no vernalization requirement. Seeds of cauliflower and broccoli were sown into modular trays of 50 cells $(4.5 \times 4.5 \mathrm{~cm})$ containing Cornell Mix A (Boodley and Sheldrake, 1977) and placed in a greenhouse at day/night temperatures of 22 to $24 / 16$ to $18{ }^{\circ} \mathrm{C}$. Seedlings were transplanted into 2-L pots containing Cornell Mix A and $5 \mathrm{~g} 14 \mathrm{~N}-$ 6.1P-11.6K controlled-release fertilizer (Osmocote 14-14-14; Scotts, Marysville, $\mathrm{OH}$ ), a slow-release fertilizer, and subsequently fertilized as required with $15 \mathrm{~N}-2.2 \mathrm{P}-12.4 \mathrm{~K}$ watersoluble fertilizer (EXCEL Cal-Mag 15-5-15; Scotts). Treatments were randomly assigned to pots on the greenhouse benches. Supplemental lighting provided $450 \mu \mathrm{mol} \cdot \mathrm{m}^{-1} \cdot \mathrm{s}^{-2}$ of photosynthetically active radiation for $14 \mathrm{~h} \cdot \mathrm{d}^{-1}$. 'Somerset' and 'Barbados' plants were kept in the greenhouse during the whole growing period.

Determining ReProductive Stage. GA applications had to occur at precisely known stages of meristem development, but that stage cannot be determined non-destructively. The exact date a particular stage is reached can vary by a few days with small variation in growing conditions. Therefore, an indirect approach was used to associate the external appearance with apical meristem maturation (Björkman and Pearson, 1998). The 
developmental stage of the broccoli apex is associated with distinctive changes in leaf shape and stem width. Plants with a meristem composed only of leaf primordia were classified as vegetative. They were classified as reproductive when the petioles of the two largest leaves were straight and the apical meristem had a central dome with a flat area in the axillary region of the leaf primordia. Plants were in a more advanced reproductive stage when they had evident paraclades and some floral primordia.

The reproductive transition and associated shoot tip changes can be detected non-destructively by a widening across the youngest exposed petioles. The width was $\approx 4 \mathrm{~mm}$ at the beginning of the adult vegetative stage in both the cauliflower and broccoli cultivars and $\approx 6 \mathrm{~mm}$ at the end of the adult vegetative period $[\approx 40 \mathrm{~d}$ after sowing (DAS)] (Fig. 1). In addition, sacrificial plants of the same cohort were dissected at regular intervals. Five plants per cultivar were dissected under a stereomicrocope (SZ-40; Olympus, Tokyo, Japan) to determine progress and 10 plants to confirm the developmental state before applying GA to the population. The shoot apical meristem diameter increased from 0.1 to $0.25 \mathrm{~mm}$ during the adult vegetative stage (Fig. 1). When the apical meristem underwent the transition to the inflorescence meristem, the petioles were slightly straightened; the tip width increased to $9 \mathrm{~mm}$ in 'Somerset' cauliflower and $8 \mathrm{~mm}$ in 'Barbados' broccoli. When a small curd began to form, the petioles bowed and the tip width increased to $13 \mathrm{~mm}$ in cauliflower and $11 \mathrm{~mm}$ in broccoli.

Shoot growth was measured two ways: as stem elongation (in centimeters) and node production rate (the number of nodes on which the leaves were longer than $5 \mathrm{~cm}$ ). Nodes appeared at
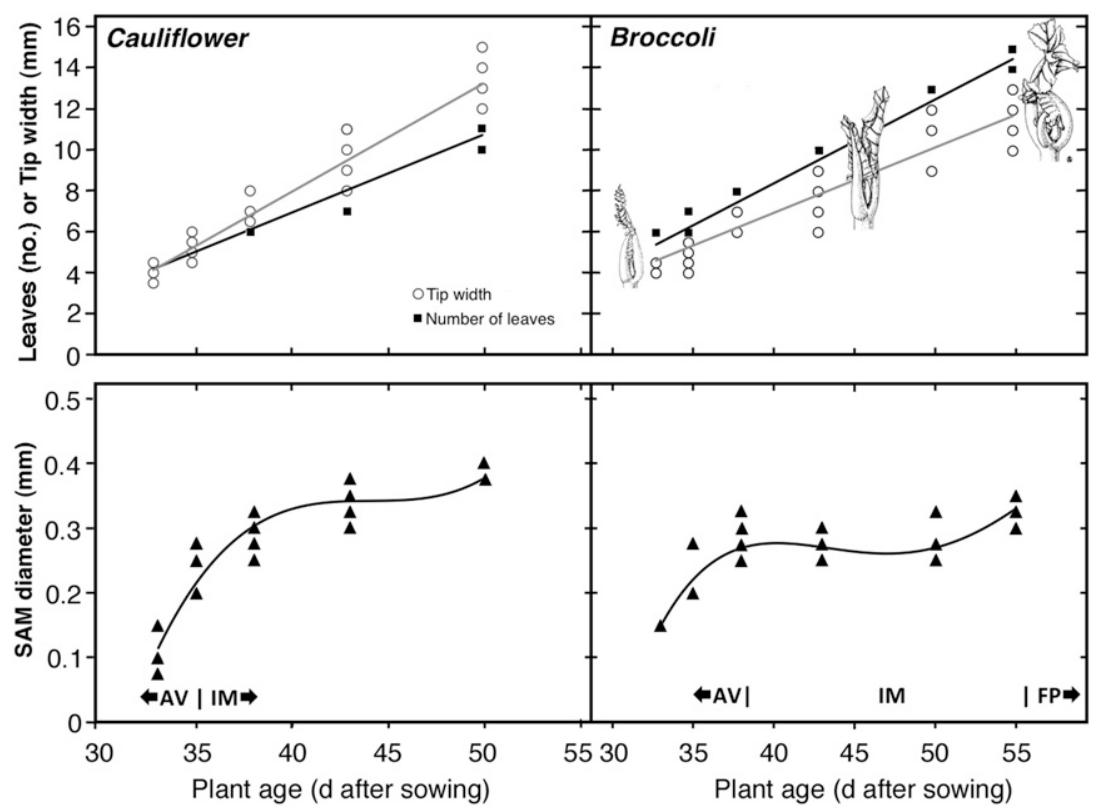

Fig. 1. Shoot growth and meristem enlargement during the transition to reproductive growth in 'Somerset' cauliflower and 'Barbados' broccoli. The number of leaves longer than $5 \mathrm{~cm}$, shoot tip width, and shoot apical meristem diameter in plants during the transition from the adult vegetative (AV) stage ( $33 \mathrm{~d}$ after sowing) through the inflorescence meristem stage (IM) until the broccoli petioles bowed, indicating the start of floralprimordium (FP) production ( 50 to $55 \mathrm{~d}$ after sowing). The values in the upper figure can be determined nondestructively to infer the diameter of the shoot apical meristem (SAM) and whether it has undergone the reproductive transition. Five plants were measured at each date. Overlapping data points are obscured; the curves were fit using all data (linear regression above, cubic spline below). Drawings to illustrate tip width and appearance are to scale and at the appropriate place on the y-axis (illustration by B. King). a consistent time interval in both cultivars. Leaf primordia were initiated before leaves were large enough to count, but the time could be inferred. In cauliflower, young leaves grew from to $3.5 \mathrm{~d}$ at the reproductive meristem stage ( $\approx 40 \mathrm{DAS})$. In roccoli, the corresponding growth rate was constant.

DETERMining ENDOgenous GAs THROUgh GA EXTRACTION PURIFICATION BY HIGH-PERFORMANCE LIQUID (GC-MS). Six bioactive GAs ( $\mathrm{GA}_{1}, \mathrm{GA}_{3}, \mathrm{GA}_{4}$, $\mathrm{GA}_{5}, \mathrm{GA}_{6}$, AND $\mathrm{GA}_{7}$ ) are produced through two different $\mathrm{GA}_{3}$, affects floral induction of cauliflower plants (Booij, 1989 1990; Guo et al., 2004), suggesting that only GAs of the non-13 hydroxylation pathway are active in the developing meristem of the plant. When studying the effects of exogenous GAs on a plant, it is important to know which of these GAs are present in the developing meristem of the plant. Booij $(1989,1990)$ and uo et al. (2004) showed that $\mathrm{GA}_{4+7}$, but not $\mathrm{GA}_{3}$, has an effect early-13 hydroxylation pathway are present in inflorescence derivatives by GC-MS after fractionation using HPLC (Ro et al., 2003). Internal standards were deuterated GAs (L. Mander, Canberra, Australia) of the following type and amount [in nanograms per gram fresh weight $(\mathrm{FW})]: \mathrm{GA}_{1}=1, \mathrm{GA}_{8}=10$, $\mathrm{GA}_{19}=10, \mathrm{GA}_{20}=20, \mathrm{GA}_{44}=5$, $\mathrm{GA}_{29}=50$, and $\mathrm{GA}_{53}=5$. GAs for which no standards were available were identified from their mass spectra by matching their Kovats' retention indices and ion masses obtained with the GC-MS with reference spectra from Gaskin and MacMillan (1991).

Exogenous GA EFFECT ON THE VEGETATIVE-TO-REPRODUCTIVE TRANSITION. We conducted two experiments on 'Somerset' cauliflower and 'Barbados' broccoli to investigate the effect of exogenous GA on heading and growth indices, indicative of floral induction. We used a well-established method that assures penetration into the meristem tissue (Mandel et al., 1992; Moore, 1967). The first experiment examined only the effect of $\mathrm{GA}_{3}$ (MC Biomedicals, Aurora, $\mathrm{OH}$ ). One microliter of a solution containing $5 \mu \mathrm{g}$ of $\mathrm{GA}_{3}, 10 \%(\mathrm{v} / \mathrm{v})$ acetone, and $0.1 \%$ wetting agent (Tween 20; Sigma-Aldrich, St. Louis, MO) or $1 \mu \mathrm{L}$ of the solution without the GA, as a control, were applied to the apical dome of each 
plant with a micropipette once daily for $2 \mathrm{~d}$ (consecutive) at the initiation of the adult vegetative stage, $\approx 30 \mathrm{DAS}$. At this stage 'Barbados' and 'Somerset' plants had five fully extended leaves and the diameter of the apical meristem was $\approx 0.2 \mathrm{~mm}$. Each treatment was applied to 12 to 15 plants.

The second experiment compared the effects of both GA and $\mathrm{GA}_{4+7}$ (PhytoTechnology Laboratories, Shawnee Mission, KS) on plants at a slightly more advanced phase of the adult vegetative stage, $\approx 38$ DAS. Again, the application time was determined by inspecting the meristem, not by the calendar. The GAs were applied as indicated above using $2 \mu \mathrm{L}$ of a solution containing $2 \mu \mathrm{g} \cdot \mu^{-1}$ of $\mathrm{GA}_{3}$ or $\mathrm{GA}_{4+7}, 25 \%(\mathrm{v} / \mathrm{v})$ ethanol, and $0.1 \%$ wetting agent. The larger apex allowed a larger volume to be used than in the first experiment. Again, the same volume of solution, without any GA, was used as a control. Applications were made once daily for $3 \mathrm{~d}$ (consecutive). This method of application provided a consistent dose of GA at the meristem, avoiding runoff, application to other plant parts, and any need for translocation within the plant. At this time, 'Somerset' cauliflower plants had six to seven fully expanded leaves and the diameter of the dissected apical meristem was $0.25 \mathrm{~mm}$. 'Barbados' broccoli plants had between seven and eight fully extended leaves and an apical meristem diameter of $0.25 \mathrm{~mm}$. Each treatment was applied to 12 plants.

In each experiment, the effect of the treatment on advancing heading and stem elongation was determined by measuring both temporal and developmental parameters: 1) curding time: the number of DAS when the curd was first visible $(\approx 1 \mathrm{~cm}$ across); 2) node production: the number of nodes formed after GA application based on the increase in the number of leaves longer than $5 \mathrm{~cm}$ between GA application and curd visibility; and 3) stem elongation: the increase in the stem height (measured from the cotyledonary attachment zone to the apical meristem of the plant) between GA application and curd visibility.

EXOGENOUS GA EFFECT ON THE MORPHOLOGY OF THE CURD. A solution containing 0 or $2.1 \mu \mathrm{g} \cdot \mu \mathrm{L}^{-1}$ of $\mathrm{GA}_{3}$ or $\mathrm{GA}_{4+7}$ in a $25 \%$ $(\mathrm{v} / \mathrm{v})$ aqueous ethyl alcohol solution and $0.1 \%$ wetting agent was applied to the apex of cauliflower and broccoli plants in a volume of $2 \mu \mathrm{L}$ once daily for $3 \mathrm{~d}$ (consecutive). Applications were made at two different stages of the reproductive development. One group of 10 plants from each cultivar was treated when the apical meristem became reproductive, as indicated by the petioles straightening, $43 \mathrm{~d}$ from sowing; a second group of 10 plants of both cultivars was treated later during inflorescence meristem proliferation but before floral bud development: 55 DAS in 'Barbados' and 50 DAS in 'Somerset'. Measurements included those described in the previous section as well as a morphological examination to determine stage of arrest. The arrest stages were categorized into one of the following classes: cauliflower, composed of inflorescence meristem; intermediate curd, composed of small floral buds and floral primordia; and broccoli, composed of fully developed floral buds.

Exogenous GA EFFECT ON BOLting. A solution containing 0 or $2.1 \mu \mathrm{g} \cdot \mu \mathrm{L}^{-1}$ of $\mathrm{GA}_{3}$ in a $25 \%(\mathrm{v} / \mathrm{v})$ aqueous ethyl alcohol solution and $0.1 \%$ Tween 20 (wetting agent) was applied to a marked location on the curd of broccoli plants once daily for $3 \mathrm{~d}$ (consecutive) beginning when flower buds had just developed (heads $\approx 2 \mathrm{~cm}$ ). The plants were photographed when the stem at the marked location elongated.
Statistical analysis of APEX Development. In every experiment, cultivars were analyzed independently with the treatments assigned in a completely randomized design with individual plants as the experimental unit. Tests for normality and equal variances were run for each variable under study to determine if assumptions of normal distribution and equal variances were met for analysis of variance (ANOVA). When the data obtained did not support the normal distribution assumption, and no transformation was possible, a nonparametric test was performed: Wilcoxon (two samples) and Kruskal-Wallis (more than two samples). Given that in some experiments observations were unequal among treatments, ANOVA was performed using PROC MIXED for its ability to estimate Type III error that corrects for unbalanced design. Multiple comparisons of the means were done using Tukey's Studentized range (honestly significantly different). Statistical analyses were performed using SAS (Version 9.1; SAS Institute, Cary, NC).

GENE EXPRESSION OF INTEGRATOR AND MERISTEM-IDENTITY Genes IN CAUliflower CV. Somerset. Four genes that are indicative of the floral transition were monitored. The change in expression of the meristem-identity genes BoAPl-a and $B o-A P 1-c$, the meristem-identity gene/integrator gene $B o L F Y$, and the integrator gene $S O C 1$ were measured in cauliflower cv. Somerset plants. Twelve uniform curds arrested at the inflorescence meristem stage and with a diameter of $\approx 5 \mathrm{~cm}$ were selected. Four milliliters of a solution containing 0 or $100 \mu \mathrm{M}$ of $\mathrm{GA}_{3}$ in a $25 \%(\mathrm{v} / \mathrm{v})$ aqueous ethyl alcohol solution and $0.1 \%$ wetting agent were applied to the entire surface of each curd with a brush. Tissue samples from two different areas of the curd were taken, using a fresh razor blade for each sample, at $0,20 \mathrm{~min}, 1 \mathrm{~h}, 3 \mathrm{~h}, 6 \mathrm{~h}$, and $24 \mathrm{~h}$ after the application. After isolation, the tissue was placed in a sterile tube, submerged in liquid nitrogen, and stored at $-80{ }^{\circ} \mathrm{C}$.

Total RNA of each sample was extracted using Trizol reagent (Invitrogen, Carlsbad, CA) following the protocol described by the manufacturer with some modifications (Duclos and Björkman, 2008). RNA reverse transcription was performed using the RETROscript kit (Ambion, Austin, $\mathrm{TX}$ ) with random decamers in accordance with the manufacturer's protocol. Gene expression was determined using SYBR Green quantitative real-time polymerase chain reaction (qRT-PCR) in the iCycler iQ Real-Time Detection System (Bio-Rad, Hercules, CA) as described by Duclos and Björkman (2008). Primer design and selection followed the guidelines outlined by Duclos and Björkman (2008); Table 1 lists the primers selected for this study. The gene expression measurements followed all 11 golden rules of qRT-PCR (Uvardi et al., 2008).

Statistical analysis of differentially expressed genes was performed with ANOVA using PROC MIXED for repeated measurement analysis, because responses were taken sequentially on the same experimental unit, in this case each plant. Each plant was considered a random effect and the GA treatment and time fixed effects. Assumption of normal distribution and equal variances were tested in each case and transformation of the data used when necessary. The statistical model developed for both genes analyzed (BoLFY and SOC1) used a compound symmetry structure. Selection followed the guidelines suggested by Littell et al. (1998) and Wolfinger and Chang (1998). 
Table 1. Primer sequences and the length of amplicon used to assess meristem differentiation in broccoli and cauliflower. ${ }^{\mathrm{z}}$

\begin{tabular}{|c|c|c|c|c|}
\hline Gene & $\begin{array}{c}\text { GenBank } \\
\text { accession no. }\end{array}$ & Forward primer & Reverse primer & $\begin{array}{l}\text { Amplicon } \\
\text { size (bp) }\end{array}$ \\
\hline$B o A P 1-a^{\mathrm{y}}$ & AJ505845 & CGAGCCCTTCTTATCCAACTAATT & CATACTGAAGCAAAAGAACTTGAGAAA & 118 \\
\hline$B o A P 1-c^{\mathrm{x}}$ & AJ505846 & TGGCTAGCTTCTTTCTATCCAATTAATA & CACATACTAGAACCAAAAACTTACAAAGAGA & 114 \\
\hline SOC1 & AY007726 & AATAGAGAATGCAACAAGCAGACAA & GAGCTCAAAGGCTTTCTTCAACA & 76 \\
\hline $18 S$ & AF513990 & CGAGACCTCAGCCTGCTAACTAG & TCAAACTTCCTTGGCCTAAACG & 93 \\
\hline
\end{tabular}

${ }^{\mathrm{z}}$ The genes are the two active loci of apetala-1(BoAPl- $a$ and BoApl-c), leafy $(B o L F Y)$, suppressor of overexpression of constans $(S O C 1)$ and the reference $18 \mathrm{~S}$ subunit of rRNA. Forward primer $(\mathrm{F})$ is $5^{\prime}$ to $3^{\prime}$; reverse primer $(\mathrm{R})$ is $3^{\prime}$ to $5^{\prime}$.

${ }^{\mathrm{y}} \mathrm{Same}$ as Boi2AP1 (U67452).

${ }^{\mathrm{x}}$ Same as BoilAP1 (U67451).

To estimate the assay variation, sES were calculated assuming statistical independence using propagation of error formulas that allow the inclusion of experimentally determined errors for each efficiency and threshold cycle $\left(\mathrm{C}_{\mathrm{t}}\right)$ value $(\mathrm{Ku}, 1966)$.

\section{Results}

ENDOGENOUS GAS IN DEVELOPING INFLORESCENCE. GAs were extracted from cauliflower curds and broccoli heads and analyzed as methyl-ester derivatives by GC-MS with deuterated internal standards. GC-MS analysis determined that methyl extracts of cauliflower contained $\mathrm{GA}_{8}, \mathrm{GA}_{29}, \mathrm{GA}_{1}$, $\mathrm{GA}_{20}$, and $\mathrm{GA}_{19}$, and broccoli extracts contained $\mathrm{GA}_{8}, \mathrm{GA}_{29}$, $\mathrm{GA}_{1}$, and $\mathrm{GA}_{20}$. All of the endogenous GAs identified using standards were from the early 13-hydroxylation pathway; $\mathrm{GA}_{44}$ was not detected in cauliflower or broccoli, although the $\mathrm{GA}_{44}$ standard was detected. The $\mathrm{GA}_{53}$ standard was never observed. $\mathrm{GA}_{53}$ is a precursor of $\mathrm{GA}_{19}$ in the early pathway. Additional GAs were identified in both cauliflower and broccoli heads by comparison with Kovats' retention indices and ion masses. These were $\mathrm{GA}_{4}, \mathrm{GA}_{12}, \mathrm{GA}_{15}$, and $\mathrm{GA}_{24}$ (from the non-13-hydroxylation pathway) and $\mathrm{GA}_{3}$ (from the early-13-hydroxylation pathway) (data not shown).

The most abundant GA observed in both cauliflower and broccoli was $\mathrm{GA}_{29}$, an inactive metabolite of $\mathrm{GA}_{20}$, with levels in cauliflower and broccoli of $167 \mathrm{ng}$ GA per gram FW and 84 ng GA per gram FW, respectively (Fig. 2). In cauliflower, the physiologically active $\mathrm{GA}_{1}$ was the second most abundant GA (5.03 ng GA per gram FW) followed by $\mathrm{GA}_{19}(4.36 \mathrm{ng} \mathrm{GA}$ per gram $\mathrm{FW}$ ), a GA that is intermediate in the biosynthesis pathway (Fig. 2). In broccoli, $\mathrm{GA}_{19}$ was not detected; instead, the subsequent precursor, $\mathrm{GA}_{20}$, was abundant (9.66 ng GA per gram FW) (Fig. 2). In the early 13-hydroxylation pathway, $\mathrm{GA}_{53}$, $\mathrm{GA}_{44}$, and $\mathrm{GA}_{19}$ are precursors of $\mathrm{GA}_{20}$; the latter is the precursor of the active gibberellin $\mathrm{GA}_{1} \cdot \mathrm{GA}_{8}$ and $\mathrm{GA}_{29}$ are inactive metabolites. These results indicate that GAs from both the early13-hydroxylation pathway (specifically, $\mathrm{GA}_{1}, \mathrm{GA}_{3}$, precursors, and inactive metabolites) and the non-13-hydroxylation pathway $\left(\mathrm{GA}_{4}\right)$ are present in inflorescence meristem and floral buds.

EFFECT OF EXOGENOUS GA ON REPRODUCTIVE INDUCTION. GA was applied to developing meristems at two different stages of vegetative development. The adult-vegetative stage was observed $34 \mathrm{DAS}$ and $\approx 16 \mathrm{~d}$ before expected inflorescence meristem initiation. At this stage, $\mathrm{GA}_{3}$ advanced the reproductive transition in both cauliflower and broccoli. The earlier transition was evident as fewer vegetative nodes and earlier curding. After $\mathrm{GA}_{3}$ application, 3.8 fewer leaves (vegetative

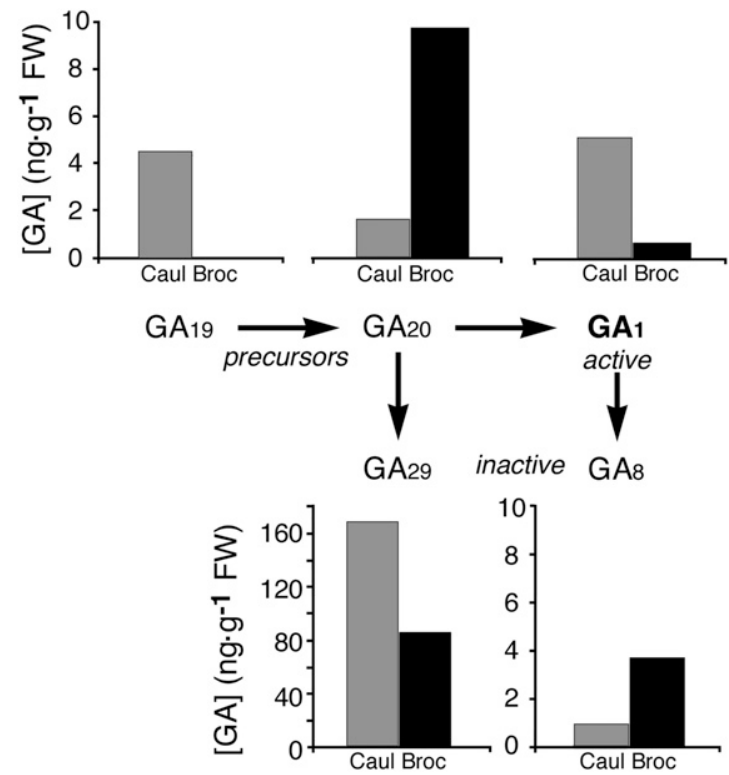

Fig. 2. Content of endogenous gibberellins in the early-13-hydroxylation biosynthetic pathways in broccoli heads [broc (black bars)] and cauliflower curds [caul (gray bars)]. $\mathrm{GA}_{19}$ and $\mathrm{GA}_{20}$ are precursors of the physiologically active gibberellin $\mathrm{GA}_{1} ; \mathrm{GA}_{8}$ is the inactive metabolite. Each column shows data from a single sample obtained from pooled tissue of three heads. GA = gibberellin.

nodes) appeared in cauliflower $(P=0.001)$ and 1.5 fewer leaves appeared in broccoli $(P=0.011)$ than in control plants (Table 2). $\mathrm{GA}_{3}$ application caused the curd to become visible $9.6 \mathrm{~d}$ earlier in cauliflower $(P=0.001)$ and $5.0 \mathrm{~d}$ earlier in broccoli $(P<$ 0.001 ) relative to controls (Table 2 ). Stem elongation increased in cauliflower; at the end of the treatment, the stem was $9.5 \mathrm{~cm}$ longer in cauliflower plants treated with $\mathrm{GA}_{3}$ than in untreated controls $(P \leq 0.001)$. No significant change in the stem length was observed in broccoli (Table 2).

When $\mathrm{GA}_{3}$ and $\mathrm{GA}_{4+7}$ were applied closer to the constitutive transition time ( $38 \mathrm{DAS}, \approx 12 \mathrm{~d}$ before expected inflorescence meristem initiation), the time to curding was significantly shorter in both inflorescence types. In cauliflower, $\mathrm{GA}_{3}$ and $\mathrm{GA}_{4+7}$ reduced the curding time by $2.2 \mathrm{~d}(P=0.025)$ and $3.6 \mathrm{~d}$ $(P=0.001)$, respectively (Table 3$)$. In broccoli, $\mathrm{GA}_{3}$ and $\mathrm{GA}_{4+7}$ reduced the curding time by $4.3 \mathrm{~d}(P=0.03)$ and by $7 \mathrm{~d}$ $(P<0.001)$, respectively.

GA application also resulted in fewer nodes being produced before the transition. As expected, the effect was smaller when application was closer to the constitutive time. The effect of 
Table 2. Effect of exogenous $\mathrm{GA}_{3}$ applied at the initiation of the adult vegetative stage, $30 \mathrm{~d}$ after sowing, on the reproductive transition in 'Barbados' broccoli and 'Somerset' cauliflower $(\mathrm{n}=15)$.

\begin{tabular}{llccc}
\hline Head type & Treatment & $\begin{array}{c}\text { Curding time } \\
{[\text { mean } \pm \mathrm{SE}(\mathrm{d})]^{\mathrm{z}}}\end{array}$ & $\begin{array}{c}\text { Nodes } \\
{[\mathrm{mean} \pm \mathrm{SE}]^{\mathrm{y}}}\end{array}$ & $\begin{array}{c}\text { Stem length } \\
{[\text { mean } \pm \mathrm{SE}(\mathrm{cm})]^{\mathrm{x}}}\end{array}$ \\
\hline Cauliflower & Control & $84.7 \pm 2.1$ & $25.2 \pm 1.3$ & $17.8 \pm 0.7$ \\
& $\mathrm{GA}_{3}$ & $75.1 \pm 1.2^{*}$ & $21.4 \pm 0.4^{*}$ & $27.3 \pm 0.5^{*}$ \\
Broccoli & $\mathrm{Control}^{*}$ & $76.3 \pm 0.4$ & $22.8 \pm 0.4$ & $41.0 \pm 1.4$ \\
& $\mathrm{GA}_{3}$ & $71.3 \pm 0.8^{*}$ & $21.3 \pm 0.3^{*}$ & $42.8 \pm 0.4$ \\
\hline
\end{tabular}

${ }^{\mathrm{z}}$ Days from sowing until the curd was visible.

${ }^{y}$ Number of leaves developed between GA treatment and when curd was visible (end of experiment). 'Increase in plant height between GA treatment and when curd was visible (end of experiment).

*Significant difference $(P<0.05)$ with respect to control. Statistical analyses of cultivars and applications within a cultivar were done independently.

$\mathrm{GA}=$ gibberellin .

Table 3. Effect of exogenous $\mathrm{GA}_{3}$ and $\mathrm{GA}_{4+7}$ applied at the end of the adult vegetative stage, $38 \mathrm{~d}$ after sowing, on the reproductive transition in 'Barbados' broccoli and 'Somerset' cauliflower $(\mathrm{n}=10)$.

\begin{tabular}{lcccc}
\hline Head type & Treatment & $\begin{array}{c}\text { Curding time } \\
{[\text { mean } \pm \text { SE }(\mathrm{d})]^{\mathrm{z}}}\end{array}$ & $\begin{array}{c}\text { Nodes } \\
{[\text { mean } \pm \mathrm{SE}]^{\mathrm{y}}}\end{array}$ & $\begin{array}{c}\text { Stem length } \\
{[\text { mean } \pm \mathrm{SE}(\mathrm{cm})]^{\mathrm{x}}}\end{array}$ \\
\hline Cauliflower & Control & $78.2 \pm 0.4$ & $18.4 \pm 0.5$ & $15.7 \pm 0.4$ \\
& $\mathrm{GA}_{3}$ & $76.0 \pm 0.7^{*}$ & $18.0 \pm 0.5$ & $16.2 \pm 0.6$ \\
Broccoli & $\mathrm{GA}_{4+7}$ & $75.0 \pm 0.5^{*}$ & $16.8 \pm 0.3^{*}$ & $18.4 \pm 0.5^{*}$ \\
& $\mathrm{Control}$ & $79.0 \pm 1.1$ & $16.4 \pm 0.4$ & $33.1 \pm 0.7$ \\
& $\mathrm{GA}_{3}$ & $74.7 \pm 1.2^{*}$ & $15.6 \pm 0.4$ & $32.9 \pm 0.9$ \\
& $\mathrm{GA}_{4+7}$ & $72.0 \pm 1.0^{*}$ & $14.4 \pm 0.5^{*}$ & $33.5 \pm 1.0$ \\
\hline
\end{tabular}

${ }^{\mathrm{z}}$ Days from sowing until the curd was visible.

${ }^{y}$ Number of leaves developed between GA treatment and when curd was visible (end of experiment).

${ }^{x}$ Increase in plant height between GA treatment and when curd was visible (end of experiment).

* Significant difference $(P<0.05)$ with respect to control. Statistical analyses done independently for each cultivar.

$\mathrm{GA}=$ gibberellin.

$\mathrm{GA}_{3}$ was smaller than that of $\mathrm{GA}_{4+7}$. In cauliflower, GA reduced the number of leaves by $1.6\left[\mathrm{GA}_{4+7}(P=0.032)\right]$ or $0.4\left[\mathrm{GA}_{3}\right.$ (non-significant)]. In broccoli, the reduction was 2.0 $\left[\mathrm{GA}_{4+7}(P=0.007)\right]$ or $0.8\left[\mathrm{GA}_{3}\right.$ (non-significant) $]$ leaves (Table 3). Stem elongation was increased by $\mathrm{GA}_{4+7}$ in cauliflower, but not in broccoli. In cauliflower, $\mathrm{GA}_{4+7}$ increased post-application elongation by $2.7 \mathrm{~cm}(P=0.003)$, but $\mathrm{GA}_{3}$ had no significant effect (Table 3 ). Overall, broccoli responded more than did cauliflower, perhaps because cauliflower was closer to the vegetative-to-reproductive transition. $\mathrm{GA}_{4+7}$ had a stronger effect than $\mathrm{GA}_{3}$ on all variables measured in both cultivars.

EFFect OF EXogenous GA ON SUBSEQUent CURD MORPHOLOGY. GA was applied to 'Somerset' cauliflower and 'Barbados' broccoli at two different stages of reproductive development: the onset of the reproductive meristem (43 DAS) and curd enlargement (50 and 55 DAS for 'Somerset' and 'Barbados', respectively). Whether applied at the beginning of reproductive meristem proliferation (43 DAS) or when it was well advanced (50 to 55 DAS), GA application did not affect the stage of arrest in either 'Somerset' cauliflower or 'Barbados' broccoli. Cauliflower plants were arrested at the inflorescence meristem stage and broccoli plants were arrested at the floral bud stage. However, application at the onset of reproductive development in 'Somerset' cauliflower plants (43 DAS) increased the development of bracts (Fig. 3). In particular, $\mathrm{GA}_{4+7}$ treatment caused all the plants to have some degree of bracting with $90 \%$ exhibiting a high degree of bracting.
GA did not significantly increase cauliflower stem elongation or node production when applied to the reproductive meristem (Table 4). Broccoli curded $3.4 \mathrm{~d}$ earlier than controls $(P=0.038)$ when $\mathrm{GA}_{4+7}$ was applied at this stage (Table 4), but the same number of nodes was produced.

Effect of exogenous GA on THE TRANSITION TO FLORAL MERISTEM IN CAULIFLOWER CURDS. To detect whether GA induces genes involved in floral-primordium initiation, the expression of three meristem-identity genes, BoLFY, $B o A P 1-a$, and BoAPl-c, and the integrator gene, $S O C 1$, was monitored after application of GA to curds of cauliflower cv. Somerset. Amplicons of BoAPl-a and $B o A P 1-c$ were not detected in any of the tissue samples taken from either the control plants or the plants treated with $\mathrm{GA}_{3}$. BoLFY expression showed no significant differences for the main effects GA $(P=0.508)$ and time $(P=$ $0.115)$ or for their interaction $(P=$ 0.247) (Fig. 4). The expression of $S O C 1$ was unaffected by the exogenous application of GA $(P=$ $0.638)$, time $(P=0.119)$, or their interaction [GA $\times$ time $(P=0.063)]$. Overall GA did not alter the expression of tested genes associated with flower development.

\section{Discussion}

The role of GA in three stages of reproductive development was tested for plant types where these transitions are well separated in time. First, we confirmed that GA advances the initial reproductive transition in vegetative plants. Second, we provide the first evidence that GA is not a signal causing reproductive meristems to begin making flower primordia. Third, we confirmed that GA induces stem elongation associated with bolting. In addition, we documented an unexpected GA-induced reversion toward vegetative character in growing cauliflower heads (Fig. 6).

GibBerellin ADVANCES REPROdUCTIVE INDUCTION IN CAULIFLOWER AND BROCCOLI. The GA pathway of reproductive induction (commonly called flowering time) varies widely in its importance among different species. In this experiment, GA substantially accelerated the transition from a vegetative to reproductive meristem. Application of $\mathrm{GA}_{3}$ and $\mathrm{GA}_{4+7}$ shortened the vegetative period in both cauliflower and broccoli. The earlier transition was evident as fewer vegetative nodes and earlier curding. This result is consistent with GA accelerating the transition from vegetative to reproductive development. In B. napus var. апnиа (Dahanayake and 


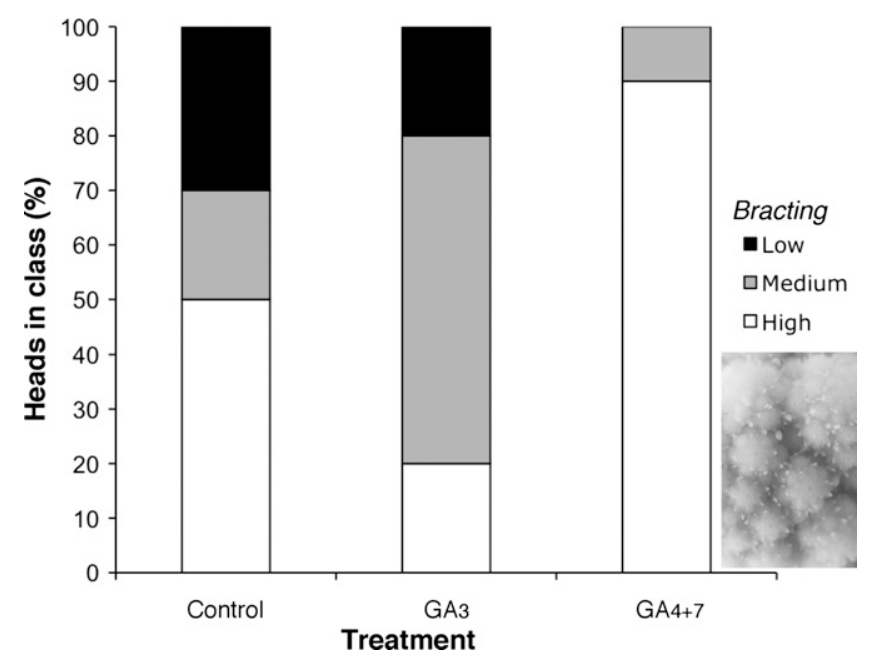

Fig. 3. Effect of gibberellin (GA) application on bracting in 'Somerset' cauliflower curds. Shown is the bract level distribution as a percentage of plants with high ( $75 \%$ to $100 \%$ of the curd containing bracts), medium $(30 \%$ to $70 \%$ of the curd containing bracts), and low (less than $30 \%$ of the curd containing bracts) bract levels in the curds after GA application when the apical meristem first became reproductive ( $43 \mathrm{~d}$ after sowing) $(\mathrm{n}=10$ for each treatment). A $\chi^{2}$ test shows higher bracting in $\mathrm{GA}_{4+7}(P=0.003)$ but not $\mathrm{GA}_{3}$ (inset: bracting on cauliflower curd of GA-treated head).

Table 4. Effect of exogenous $\mathrm{GA}_{3}$ and $\mathrm{GA}_{4+7}$ on the reproductive transition in 'Barbados' broccoli and 'Somerset' cauliflower when applied in the early inflorescence meristem stage ( $43 \mathrm{~d}$ after sowing) and in the middle of the inflorescence meristem stage ( $55 \mathrm{~d}$ after sowing) $(\mathrm{n}=12)$.

\begin{tabular}{|c|c|c|c|c|}
\hline Head type & Treatment & $\begin{array}{c}\text { Curding time } \\
{[\text { mean } \pm \text { SE }(d)]^{\mathrm{z}}}\end{array}$ & $\begin{array}{c}\text { Nodes } \\
{[\text { mean } \pm \mathrm{SE}]^{\mathrm{y}}}\end{array}$ & $\begin{array}{c}\text { Stem length } \\
{[\text { mean } \pm \mathrm{SE}(\mathrm{cm})]^{\mathrm{x}}}\end{array}$ \\
\hline & \multicolumn{4}{|c|}{ Application at early inflorescence meristem stage } \\
\hline \multirow[t]{3}{*}{ Cauliflower } & Control & $76.3 \pm 0.7$ & $15.0 \pm 0.6$ & $13.1 \pm 0.5$ \\
\hline & $\mathrm{GA}_{3}$ & $76.7 \pm 0.6$ & $15.2 \pm 0.4$ & $14.0 \pm 0.9$ \\
\hline & $\mathrm{GA}_{4+7}$ & $74.4 \pm 0.7$ & $14.2 \pm 0.3$ & $15.2 \pm 0.4$ \\
\hline \multirow[t]{3}{*}{ Broccoli } & Control & $77.0 \pm 0.7$ & $13.9 \pm 0.3$ & $29.2 \pm 0.6$ \\
\hline & $\mathrm{GA}_{3}$ & $77.0 \pm 1.1$ & $13.9 \pm 0.4$ & $30.0 \pm 0.7$ \\
\hline & $\mathrm{GA}_{4+7}$ & $73.6 \pm 1.0^{*}$ & $12.9 \pm 0.4$ & $28.1 \pm 1.1$ \\
\hline
\end{tabular}

\begin{tabular}{llrrr} 
& \multicolumn{4}{c}{ Application at middle inflorescence meristem stage } \\
Cauliflower & Control & $76.0 \pm 0.9$ & $12.4 \pm 0.8$ & $9.9 \pm 0.7$ \\
& $\mathrm{GA}_{3}$ & $77.7 \pm 0.5$ & $13.4 \pm 0.7$ & $11.7 \pm 0.5$ \\
\multirow{3}{*}{ Broccoli } & $\mathrm{GA}_{4+7}$ & $77.8 \pm 0.6$ & $13.3 \pm 0.4$ & $12.6 \pm 0.6$ \\
& Control & $76.7 \pm 1.0$ & $7.5 \pm 0.5$ & $19.6 \pm 0.9$ \\
& $\mathrm{GA}_{3}$ & $77.7 \pm 0.7$ & $8.1 \pm 0.5$ & $20.7 \pm 1.0$ \\
& $\mathrm{GA}_{4+7}$ & $77.3 \pm 0.9$ & $8.5 \pm 0.4$ & $20.4 \pm 0.7$
\end{tabular}

${ }^{\mathrm{z}}$ Days from sowing until the curd was visible.

${ }^{y}$ Number of leaves developed between GA treatment and when curd was visible (end of experiment). 'Increase in plant height between GA treatment and when curd was visible (end of experiment).

* Significant difference $(P<0.05)$ with respect to control. Statistical analyses of cultivars and applications within a cultivar were done independently.

$\mathrm{GA}=$ gibberellin.

Galwey, 1999), exogenous application of $\mathrm{GA}_{3}$ was shown to reduce the number of nodes at flowering and the time to flowering, similar to the results shown for cauliflower and broccoli in the present study.

GibBERELLIN DOES NOT CONTROL THE TRANSITION FROM INFLORESCENCE MERISTEM TO FLORAL PRIMORDIUM IN CAULIFLOWER AND BROCCOLI. The long duration of the inflorescence meristem stage is the defining trait of cauliflower and broccoli. In cauliflower, the inflorescence meristem stage continues until harvest without flower induction. The potential broccoli to form so many flower buds at once is the uence of the extended proliferation of inflorescence primordia. These distinctive phenotypes are produced because oral primordia are induced in the inflorescence meristem at 作 meristem to floral primordium in either 'Somerset' cauliflower or 'Barbados' broccoli plants. No change in the stage of (he (1990) similarly found no cauliflower curds after $\mathrm{GA}_{4+7}$ treatments in summer cauliflowers. The GA content of leaves has

In cauliflower, GA application also did not cause detectable upregulation of the meristem-identity genes BoAPl- $a$ and $B o A P 1-c$, which would be indicative of reproductive induction. Although GAs are known to accelerate the transition from vegetative to reproductive meristem in arabidopsis by upg LFY and SOC1 (Blazquez et al., 1998; Gocal et al., 2001; Moon et al., 2003), the homologous genes were not upregulated in cauliflower inflorescence meristems (Fig. 4). The increase in $B O A P 1-a$ and $B o A P 1-c$ transcript levels observed in 'Green Harmony' cauliflower just before floral-primordium initiation and the BoLFY expression observed once plants are in the reproductive stage (Duclos and Björkman, 2008) are therefore not caused by an increase in GA. Moreover, it could be caused by exactly the opposite, a decrease in the levels of the phytohormone. In this regard, cauliflower resembles arabidopsis, where GAs applied during reproductive development do not activate meristemidentity genes or A-function genes (Yu et al., 2004). In fact, in arabidopsis, the promotion of flowering occurs as a result of a reduction in GA by a GA catabolism gene that is up-regulated by $L F Y$ (Yamaguchi et al., 2014).

Gibberellin and bolting. GA induces bolting-associated stem elongation (Hamano et al., 2002). That function of GA was confirmed for broccoli in these tests. When $\mathrm{GA}_{3}$ was applied to small heads of 'Barbados' broccoli plants just after buds had developed, the area of the curd receiving the GA drop subsequently developed an elongated stalk, whereas the rest of the head remained compact (Fig. 5). Such stalk elongation normally occurs later, when the whole head elongates at the time of coordinated anthesis.

In broccoli, applied GAs had no effect on the stage of the arrest. Flower buds were developed and remained unopened. GA also increased stem elongation to some extent during the 


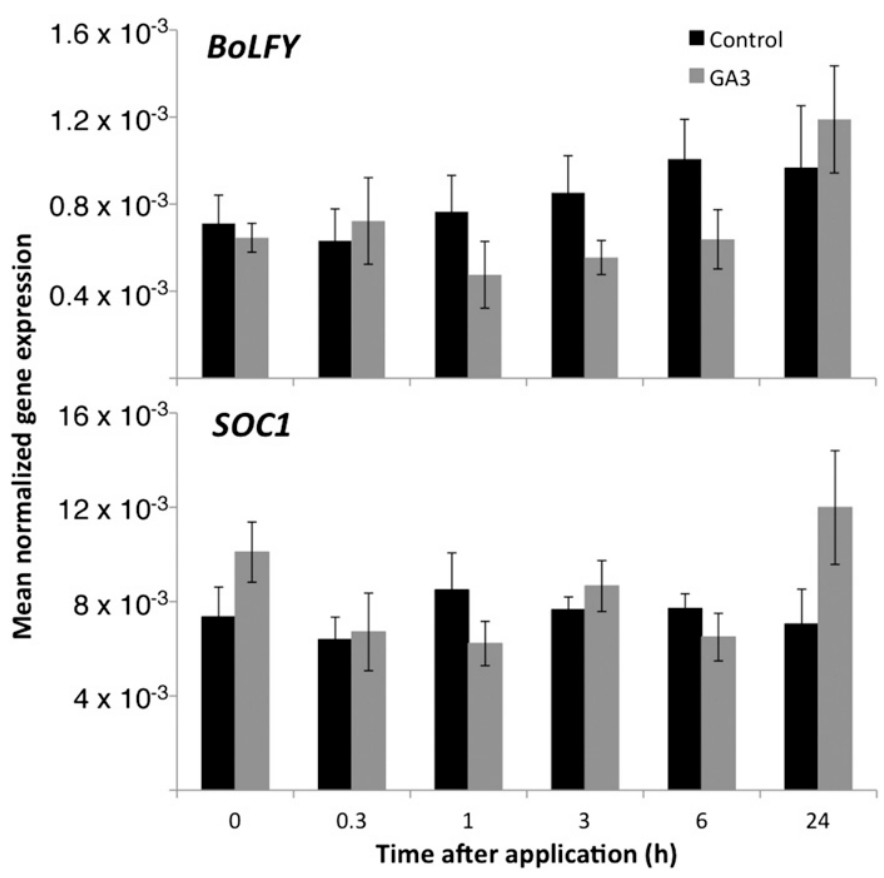

Fig. 4. Effect of exogenous $\mathrm{GA}_{3}$ on the expression of $B o L F Y$ and $S O C 1$. The relative transcript abundance after application of $\mathrm{GA}_{3}$ (gray columns) or a solvent control (black columns) in curds of 'Somerset' cauliflower plants arrested at the inflorescence meristem stage. Expression is relative to $18 \mathrm{~S}$ rRNA. Columns are means $\pm \operatorname{SE}(n=6)$. GA $=$ gibberellin.

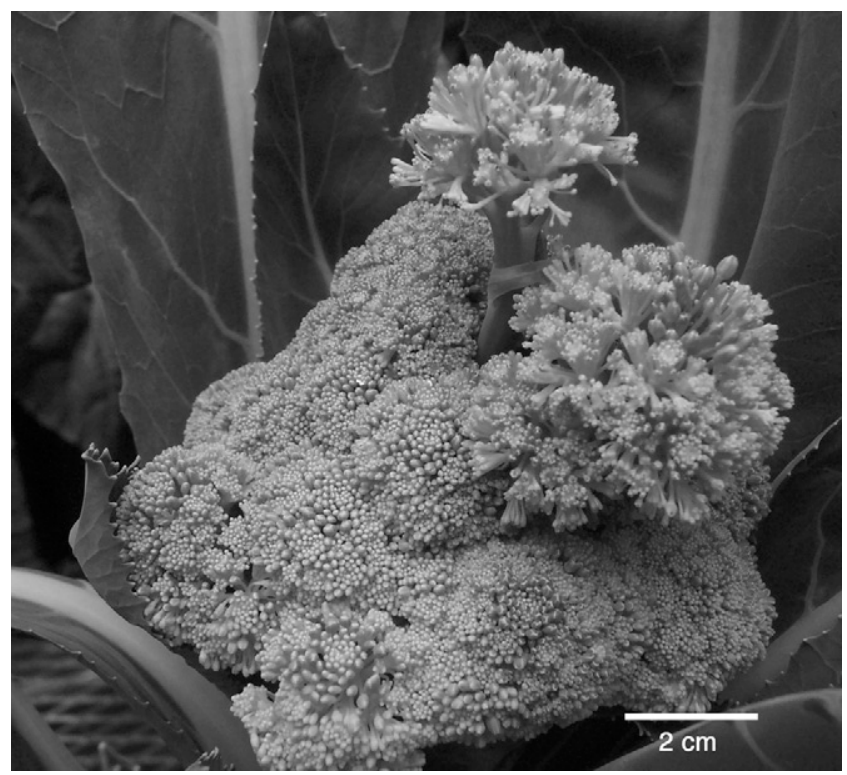

Fig. 5. Effect of exogenous $\mathrm{GA}_{3}$ in 'Barbados' broccoli plants when applied at the initiation of the headed stage, after floral bud formation. Two stems elongated where GA was applied directly to the broccoli head when it was $2 \mathrm{~cm}$ diameter. $\mathrm{GA}=$ gibberellin.

vegetative stage when GA was applied to the apex. As part of the test of reproductive induction, cauliflower produced longer internodes after GA application early in the adult vegetative stage. No effect of the hormone was observed when its application was closer to reproductive commitment (Tables 2 to 4). The same was observed in broccoli.
Gibberellin, BRACTING, AND Vegetative REVERSiOn IN CAULIFLOWER. Although GA generally promotes reproductive development (Andrés and Coupland, 2012; Srikanth and Schmid, 2011), in one respect it promoted vegetative reversion. In 'Somerset' cauliflower, application of GAs to the inflorescence meristem at the initiation of reproductive development increased the incidence of bracts in mature heads (Fig. 3). The effect was particularly pronounced with $\mathrm{GA}_{4+7}$, in which greater than $90 \%$ of observed curds developed many bracts. Bracting results from the release of leaf primordia subtending each inflorescence meristem. "Bracty" curds have bracteoles forming around each flower primordium, manifesting a reversion of the reproductive phase to a vegetative phase (Grevsen et al., 2003). In many perennial species, the application of exogenous GAs has caused reversion from reproductive to vegetative development (reviewed by Bergonzi and Albani, 2011). However, this result was not expected based on previous reports in cauliflower and arabidopsis. Booij (1990) found less bracting after applying $\mathrm{GA}_{4+7}$ to cauliflower. In arabidopsis, floral-meristem reversion has been associated with a decrease in GA levels or GA activity (Okamuro et al., 1996), reduced levels of $L F Y$ (Ferrandiz et al., 2000), and consequently reduced upregulation of $A P 1$ (Liljegren et al., 1999). This contradiction might be explained if the GA response is concentration-dependent in B. oleracea. In Pharbitis nil for example, a high dose of GAs suppresses floral induction and a low dose accelerates flowering (King et al., 2000). Exogenous application of GA may have caused a reversion-inducing concentration of GA immediately after the vegetative-to-reproductive transition. Because $\mathrm{GA}_{4+7}$ had a stronger effect than $\mathrm{GA}_{3}$ in bract incidence, the early and non-hydroxylation pathways may be controlling this process differentially. The inconsistent bracting response between this early-maturing cultivar and others reported in the literature may reflect the effect of variation in the bracting genes previously identified by Dickson and Lee (1980).

GENETIC VARIATION IN GA RESPONSE AMONG CAULIFLOWER CULTIVARS. The present results differ from some previous studies regarding the effect of $\mathrm{GA}_{3}$ and $\mathrm{GA}_{4+7}$ in floral induction of cauliflower and broccoli. To some extent, that difference reflects genetic variation in the flower development among cultivars. In arabidopsis the reproductive transition is controlled by a complex network of five flowering pathways that involve response to GA as well as daylength, vernalization, carbohydrates, and an age-related autonomous pathway. In $B$. oleracea, the wide diversity of inflorescence timing and morphology among cultivars implies wide variation within the species in the relative influence of each of those five pathways. Indeed, several distinct quantitative trait loci have been identified for each of the two developmental transitions (Uptmoor et al., 2012). An example is the varying effect of GA among cauliflowers that vary in their vernalization requirement. Leshem and Steiner (1968) found that $\mathrm{GA}_{3}$ potentiated but did not substitute for vernalization in reducing the number of nodes before curd formation and accelerating flowering in a winter cauliflower. However, in temperate [cv. Lawyna (Aditya and Fordham, 1995) and fall cauliflower [cv. Nautilus (Fernandez et al., 1997)], GAs did not potentiate vernalization but alone induced earlier curd formation when applied under weak curd-inducing conditions. 'Somerset', the summer cauliflower used in the present study, does not require 

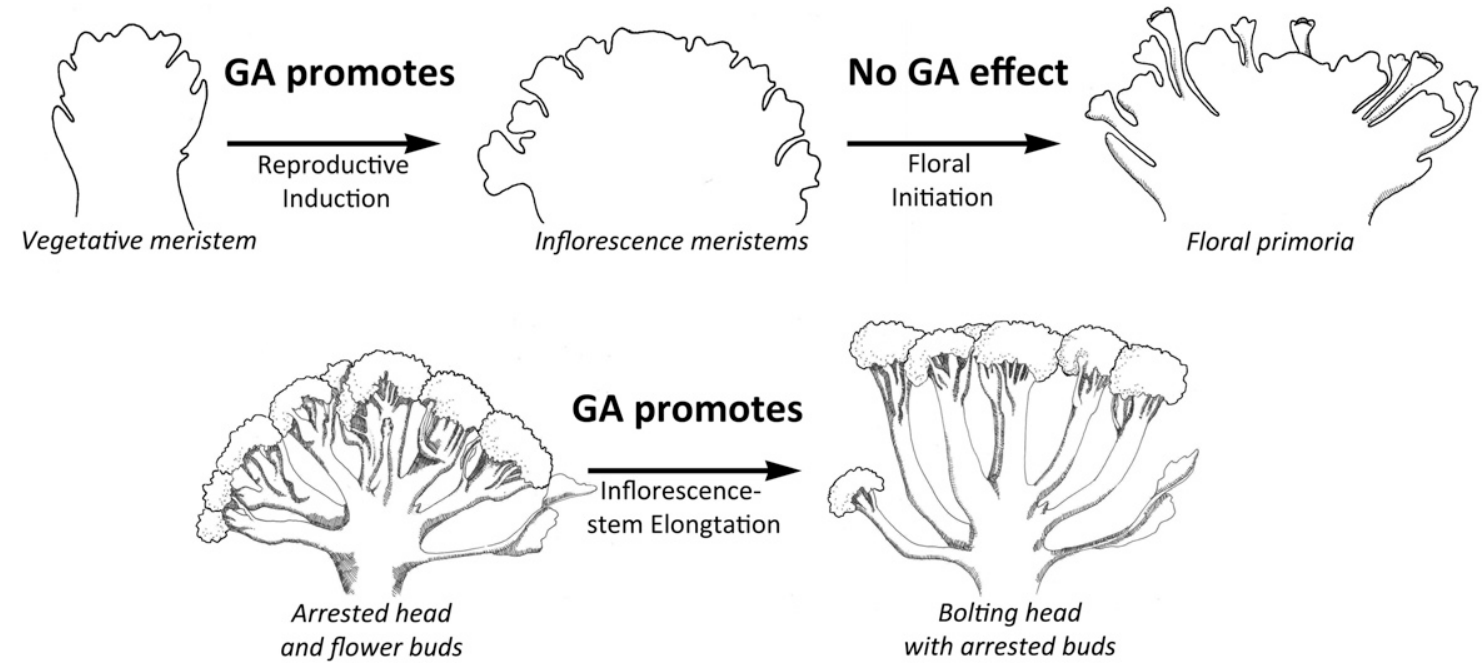

Fig. 6. Gibberellin (GA) sensitivity of three developmental steps in broccoli inflorescence. Three developmental processes in inflorescence development were tested for regulation by GA. GA promotes the transition from vegetative to reproductive meristem. GA has no role in promoting flower initiation once the meristem is reproductive. GA promotes stem elongation associated with bolting once the flower buds are formed (illustration by M. Carlson).

vernalization to form the curd. Therefore, fewer induction pathways are involved in the vegetative-to-reproductive transition, and the relative importance of the GA pathway is likely increased. The positive response of 'Somerset' to both GAs supports the model that the GA response exists in all cauliflower, but it is masked in those with a strong vernalization requirement.

It has been an open question whether GAs from both hydroxylation pathways are active in cauliflower. Both pathways have been found in other brassicas $[B$. oleracea var. capitata (Hamano et al., 2002), Raphanus sativus (Nishijima et al., 1998), and arabidopsis (Talon et al., 1990)]. However, GAs in the early-13-hydroxylated pathway $\left(\mathrm{GA}_{1}, \mathrm{GA}_{3}\right)$ were previously found not to induce flowering in summer or fall cauliflowers ['Delira' (Booij, 1989, 1990); 'Nautilus' (Fernandez et al., 1997)], raising the possibility that this pathway is absent. It is also possible that the response to $\mathrm{GA}_{1}$ and $\mathrm{GA}_{3}$ was not detected in earlier work if they were applied before or after the brief responsive stage or if application to leaves did not result in a sufficient dose at the meristem.

Here, 'Somerset' cauliflower and 'Barbados' broccoli responded to both $\mathrm{GA}_{3}$ (early 13-hydroxylation pathway) and $\mathrm{GA}_{4+7}$ (non-13-hydroxylation pathway); also, GAs from both pathways were present in the curds, indicating that both the early 13-hydroxylation pathway and the non-13-hydroxylation pathway are present and active in inflorescence meristem and floral buds of these cultivars.

\section{Summary}

Under the experimental conditions presented in this study, GAs trigger the vegetative-to-reproductive transition in both 'Somerset' cauliflower and 'Barbados' broccoli and accelerate bud development in broccoli cultivars. GAs, however, do not advance the inflorescence-meristem-to-floral-primordium transition; on the contrary, they produce floral reversion increasing bract incidence in 'Somerset' cauliflower.

\section{Literature Cited}

Aditya, D.K. and R. Fordham. 1995. Effects of cold treatment and of gibberellic acid on flowering of cauliflower. J. Hort. Sci. 70:577-585. Andrés, F. and G. Coupland. 2012. The genetic basis of flowering responses to seasonal cues. Nat. Rev. Genet. 13:627-639.

Bergonzi, S. and M.C. Albani. 2011. Reproductive competence from an annual and a perennial perspective. J. Expt. Bot. 62:4415-4422.

Björkman, T. and K.J. Pearson. 1998. High temperature arrest of inflorescence development in broccoli (Brassica oleracea var. italica L.). J. Expt. Bot. 49:101-106.

Blazquez, M.A., R. Green, O. Nilsson, M.R. Sussman, and D. Weigel. 1998. Gibberellins promote flowering of Arabidopsis by activating the LEAFY promoter. Plant Cell 10:791-800.

Blazquez, M.A. and D. Weigel. 2000. Integration of floral inductive signals in Arabidopsis. Nature 404:889-892.

Bonhomme, F., B. Kurz, S. Melzer, G. Bernier, and A. Jacqmard. 2000. Cytokinin and gibberellin activate SaMADS A, a gene apparently involved in regulation of the floral transition in Sinapis alba. Plant J. 24:103-111.

Boodley, J.W. and R. Sheldrake. 1977. Cornell peat-lite mixes for commercial plant growing. Cornell Univ. Coop. Ext. Info. Bul. 43.

Booij, R. 1989. Effect of growth-regulators on curd diameter of cauliflower. Sci. Hort. 38:23-32.

Booij, R. 1990. Effects of gibberellic acids on time of maturity and on yield and quality of cauliflower. Neth. J. Agr. Sci. 38:641-651.

Boss, P.K., E.J. Buckeridge, A. Poole, and M.R. Thomas. 2003. New insights into grapevine flowering. Funct. Plant Biol. 30:593-606.

Bowman, J.L., J. Alvarez, D. Weigel, E.M. Meyerowitz, and D.R. Smyth. 1993. Control of flower development in Arabidopsis thaliana by APETALA1 and interacting genes. Development 119:721-743.

Coen, E.S. and E.M. Meyerowitz. 1991. The war of the whorls: Genetic interactions controlling flower development. Nature 353:31-37.

Corbesier, L., G. Kustermans, C. Perilleux, S. Melzer, T. Moritz, A. Havelange, and G. Bernier. 2004. Gibberellins and the floral transition in Sinapis alba. Physiol. Plant. 122:152-158.

Dahanayake, S.R. and N.W. Galwey. 1999. Effects of interactions between low-temperature treatments, gibberellin $\left(\mathrm{GA}_{3}\right)$ and photoperiod on flowering and stem height of spring rape (Brassica napus var. апnиa). Ann. Bot. (Lond.) 84:321-327.

Dickson, M.H. and C.Y. Lee. 1980. Persistent white curd and other curd characters of cauliflower. J. Amer. Soc. Hort. Sci. 105:533-535. 
Duclos, D.V. and T. Björkman. 2008. Meristem identity gene expression during curd proliferation and flower initiation in Brassica oleracea. J. Expt. Bot. 59:421-433.

Farnham, M. and T. Björkman. 2011. Evaluation of experimental broccoli hybrids developed for summer production in the eastern United States. HortScience 46:858-863.

Favaro, R., A. Pinyopich, R. Battaglia, M. Kooiker, L. Borghi, G. Ditta, M.F. Yanofsky, M.M. Kater, and L. Colombo. 2003. MADSbox protein complexes control carpel and ovule development in Arabidopsis. Plant Cell 15:2603-2611.

Fernandez, J.A., S. Banon, J.A. Franco, A. Gonzalez, and P.F. Martinez. 1997. Effects of vernalization and exogenous gibberellins on curd induction and carbohydrate levels in the apex of cauliflower (Brassica oleracea var. botrytis). Sci. Hort. 70:223-230.

Ferrandiz, C., Q. Gu, R. Martienssen, and M.F. Yanofsky. 2000. Redundant regulation of meristem identity and plant architecture by FRUITFULL, APETALA1 and CAULIFLOWER. Development 127:725-734.

Fontes, M.R. and J.L. Ozbun. 1970. Effect of growth retardants on growth and flowering of broccoli. HortScience 5:483-484.

Fujime, Y. and N. Okuda. 1996. The physiology of flowering in Brassicas, especially about cauliflower and broccoli. Acta Hort. 407:247-254.

Gaskin, P. and J. MacMillan. 1991. GC-MS of the gibberellins and related compounds: Methodology and a library of spectra. Cantock's Enterprises, Bristol, UK.

Gocal, G.F.W., C.C. Sheldon, F. Gubler, T. Moritz, D.J. Bagnall, C.P. MacMillan, S.F. Li, R.W. Parish, E.S. Dennis, D. Weigel, and R.W. King. 2001. GAMYB-like genes, flowering, and gibberellin signaling in Arabidopsis. Plant Physiol. 127:1682-1693.

Grevsen, K., J.E. Olesen, and B. Veierskov. 2003. Effects of temperature and plant developmental stage on the occurrence of the curd quality defects 'bracting' and 'riciness' in cauliflower. J. Hort. Sci. Biotechnol. 78:638-646.

Guo, D.P., G. Ali Shah, G.W. Zeng, and S.J. Zheng. 2004. The interaction of plant growth regulators and vernalization on the growth and flowering of cauliflower (Brassica oleracea var. botrytis). J. Plant Growth Regul. 43:163-171.

Hamano, M., Y. Yamato, H. Yamazaki, and H. Miura. 2002. Endogenous gibberellins and their effects on flowering and stem elongation in cabbage (Brassica oleracea var. capitata). J. Hort. Sci. Biotechnol. 77:220-225.

Huang, Q. 1996. Effects of plant growth regulators on endogenous hormones and bud differentiation of longan. Acta Bot. Yunnan 18:145-150.

Jiang, X., X. Yu, and D. Li. 2011. Meristem development and its relation to endogenous $\mathrm{GA}_{3}$ and IAA contents during floral bud differentiation in broccoli J. Bangladesh Acad. Sci. 3:1-6.

King, R.W., T. Moritz, L.T. Evans, O. Junttila, and A.J. Herlt. 2001. Long-day induction of flowering in Lolium temulentum involves sequential increases in specific gibberellins at the shoot apex. Plant Physiol. 127:624-632.

King, R.W., H. Seto, and R.M. Sachs. 2000. Response to gibberellin structural variants shows that ability to inhibit flowering correlates with effectiveness for promoting stem elongation of some plant species. J. Plant Growth Regul. 19:437-444.

$\mathrm{Ku}, \mathrm{H}$. 1966. Notes on the use of propagation of error formulas. J. Res. Natl. Bur. Stand., C Eng. Instrum. 70C:263-273.

Lang, A. 1957. The effect of gibberellin upon flower formation. Proc. Natl. Acad. Sci. USA 43:709-717.

Leshem, Y. and S. Steiner. 1968. Effect of gibberellic acid and cold treatment on flower differentiation and stem elongation of cauliflower, Brassica oleracea var. botrytis. Isr. J. Agr. Res. 18:133134.

Liljegren, S.J., C. Gustafson-Brown, A. Pinyopich, G.S. Ditta, and M.F. Yanofsky. 1999. Interactions among APETALA1, LEAFY, and TERMINAL FLOWER1 specify meristem fate. Plant Cell 11:10071018.
Littell, R.C., P.R. Henry, and C.B. Ammerman. 1998. Statistical analysis of repeated measures data using SAS procedures. J. Anim. Sci. 76:1216-1231.

Luukkanen, O. and S. Johansson. 1980. Effect of exogenous gibberellins on flowering in Pinus sylvestris grafts. Physiol. Plant. 50:365370 .

Mandel, R.M., S.B. Rood, and R.P. Pharis. 1992. Bolting and floral induction in annual and cold-requiring biennial Brassica spp.: Effects of photoperiod and exogenous gibberellin, p. 371-379. In: Karssen, C.M., L.C. Vanloon, and D. Vreugdenhil (eds.). Progress in plant growth regulation. Kluwer Academic Publ., Dordrecht, The Netherlands.

Moon, J., S.S. Suh, H. Lee, K.R. Choi, C.B. Hong, N.C. Paek, S.G. Kim, and I. Lee. 2003. The SOC1 MADS-box gene integrates vernalization and gibberellin signals for flowering in Arabidopsis. Plant J. 35:613-623.

Moore, T.C. 1967. Gibberellin relationships in the 'Alaska' pea (Pisum sativum). Amer. J. Bot. 54:262-269.

Naor, V., J. Kigel, and M. Ziv. 2004. Hormonal control of inflorescence development in plantlets of calla lily (Zantedeschia spp.) grown in vitro. J. Plant Growth Regul. 42:7-14.

Nishijima, T., N. Katsura, M. Koshioka, H. Yamazaki, M. Nakayama, H. Yamane, I. Yamaguchi, T. Yokota, N. Murofushi, N. Takahashi, and M. Nonaka. 1998. Effects of gibberellins and gibberellinbiosynthesis inhibitors on stem elongation and flowering of Raphanus sativus L. J. Jpn. Soc. Hort. Sci. 67:325-330.

Okamuro, J.K., B.G. den Boer, C. Lotys-Prass, W. Szeto, and K.D. Jofuku. 1996. Flowers into shoots: Photo and hormonal control of a meristem identity switch in Arabidopsis. Proc. Natl. Acad. Sci. USA 93:13831-13836.

Oosthuyse, S.A. 1995. Effect of aqueous application of $\mathrm{GA}_{3}$ on flowering of mango trees: Why in certain instances is flowering prevented, and in others flowering is only delayed? Yearbook South African Mango Growers'Assn. 15:21-25.

Pelaz, S., G.S. Ditta, E. Baumann, E. Wisman, and M.F. Yanofsky. 2000. B and C floral organ identity functions require SEPALLATA MADS-box genes. Nature 405:200-203.

Posé, D., L. Yant, and M. Schmid. 2012. The end of innocence: Flowering networks explode in complexity. Curr. Opin. Plant Biol. $15: 45-50$.

Rosin, F.M., J.K. Hart, H.T. Horner, P.J. Davies, and D.J. Hannapel. 2003. Overexpression of a knotted-like homeobox gene of potato alters vegetative development by decreasing gibberellin accumulation. Plant Physiol. 132:106-117.

Ross, S.D., M.P. Bollman, R.P. Pharis, and G.B. Sweet. 1984. Gibberellin $\mathrm{A}_{4+7}$ and the promotion of flowering in Pinus radiata. Effects of partitioning of photoassimilate within the bud during primordia differentiation. Plant Physiol. 76:326-330.

Sadik, S. 1962. Morphology of the curd of cauliflower. Amer. J. Bot. 49:290-297.

Shannon, S. and D.R. Meeks-Wagner. 1993. Genetic interactions that regulate inflorescence development in Arabidopsis. Plant Cell 5:639-655.

Simpson, G.G. and C. Dean. 2002. Arabidopsis, the Rosetta stone of flowering time? Science 296:285-289.

Sponsela, V.M. and P. Hedden. 2004. Gibberellin biosynthesis and catabolism, p. 63-94. In: Davies, P.J. (ed.). Plant hormones. Biosynthesis, signal transduction, action! Kluwer Academic Publ., Dordrecht, The Netherlands.

Srikanth, A. and M. Schmid. 2011. Regulation of flowering time: All roads lead to Rome. Cell. Mol. Life Sci. 68:2013-2037.

Talon, M., M. Koornneef, and J.A.D. Zeevaart. 1990. Endogenous gibberellins in Arabidopsis thaliana and possible steps blocked in the biosynthetic pathways of the semidwarf ga4 and ga5 mutants. Proc. Natl. Acad. Sci. USA 87:7983-7987.

Uptmoor, R., J. Li, T. Schrag, and H. Stützel. 2012. Prediction of flowering time in Brassica oleracea using a quantitative trait locibased phenology model. Plant Biol. 14:179-189. 
Uvardi, M., T. Czechowski, and W.-R. Scheible. 2008. Eleven golden rules of quantitative RT-PCR. Plant Cell 20:1736-1737.

Wittwer, S.H. and M.J. Bukovac. 1957. Gibberellin effects on temperature and photoperiodic requirements for flowering of some plants. Science 126:30-31.

Wolfinger, R.D. and M. Chang. 1998. Comparing the SAS GLM and MIXED procedures for repeated measures. SAS Inst., Cary, NC.

Yahyaoui, T., M. Barbier, and R. Bessis. 1998. In vitro morphogenesis of grapevine (Vitis vinifera L.) inflorescence primordia, cvs.
Pinot Noir and Chardonnay. Austral. J. Grape Wine Res. 4:111120.

Yamaguchi, N., C.M. Winter, M.-F. Wu, Y. Kanno, A. Yamaguchi, M. Seo, and D. Wagner. 2014. Gibberellin acts positively then negatively to control onset of flower formation in Arabidopsis. Science 344:638-641.

Yu, H., T. Ito, Y. Zhao, J. Peng, P. Kumar, and E.M. Meyerowitz. 2004. Floral homeotic genes are targets of gibberellin signaling in flower development. Proc. Natl. Acad. Sci. USA 101:78277832 . 